\title{
A ORGANIZAÇÃO DA ROTA ATLÂNTICA DO OURO DA MINA E OS MECANISMOS DOS RESGATES.
}

\section{A ORGANIZAÇÃO DA ROTA.}

Estabelecidas as bases firmes de um comércio regular com os reinos negros da Senegâmbia e com as comunidades bérberes do Saara atlântico, Portugal mobilizou-se para completar a "captura" do ouro sudanês com a organização atlântica da rota da Mina.

As expedições de Cadamosto (1) e de Diogo Gomes (2) haviam levado ao reino uma verdadeira "Aleluia". Por elas Portugal pôde recolher preciosos informes sôbre os caminhos do ouro, ao mesmo tempo que estabeleceu em sólidas linhas contacto regular com os aldeiamentos mandingas do Senegal e do Gâmbia. Os próprios cronistas e viajantes árabes não tinham logrado traçar com precisão os mecanismos da troca e a procedência do rico metal amarelo que os portuguêses, agora, desviavam para o Atlântico. A construção da feitoria-fortaleza de Arguim, consagração de tôda a política da expansão henriquina, e valiosa base de penetração continental, destina-

(1). - As viagens de Cadamosto foram publicadas pela primeira vez em 1507, em Vicência na compilação - Paesi Nurovkmente Retrovati Et Novo Mondo da Alberico Vesputib Flonentino intitulato, com o título: Aloysio de Cadamosto libro della prima navigatione per Oceano alla terra de Negri et della bassa Ethiopia, per command'umento del Infante $D$. Henrico di Portogallo. Sucessivamente, as narrativas das suas viagens foram publicadar em ediç̧ōes italianas e versões latinas, portuguêsas, etc. (Cf. Cíddeo, Rlnaldo - Le Navidazioni atlantichi di Alvise da $\mathrm{Ca}$ da Mosto. Milão, 1929; Viagens de Luís de Cadamosto e de Pedro de Sintra - textos italiano e portugues - - ed. da Academiłà Portuguêsa đa Históría, Lisboa, 1948; Naveģaçōes 1.a e 2.a do Luís de Cadamosto - textos italiano e português - in Silva Marques Descobrimentos Portuguêses. Docurmentos para a sua história, suplemento ao v. I, págs. 164-248. Lisboa, 1944; Ramusio, G. B. - Navigatione del $M$. Aluise da Ca da Mosto in Delle NGvígationi et Viaggi, págs. 96 e segs. Veneza, 1563.

(2). - Cf. As Relaçoóes do descobrimento da Guiné el das ilhas dos Açores, Madeira e Cabo Verde. Versão do latim por Gabriel Pereira. Bol. da Sociedade de Geografia de Lisboa, n.0 5. Lisboał 1900. 
va-se a desviar em proveito do mar as velhas trilhas do ouro sudanês que, desde recuados tempos, fizeram a fortuna dos mercad as da orla mediterrânea.

Mas os estabelecimentos de Arguim, ponto de partida para a "captura" atlântica, não bastavam. Impunha-se organizar o trato no coração da "Terra dos Negros", além da Senegâmbia, numa área geográfica a mais próxima possível das regiões auríferas, completamente ignorada dos nômades cameleirosi do deserto, clientes do Tombuctú (3).

Com a perseverante execução do plano de absorção do comércio do ouro, e de desvio do seu trânsito das pistas transaarianas para o Atlântico, é que Pedro de Sintra empreendeu a sua viagem (4) à Serra Leoa (5) .

Pedro de Sintra, escudeiro de Afonso V, foi o continuador dos descobrimentos realizados por Cadamosto e Diogo Gomes.

(3). - A costa dia Africa Negra não figurava, então, na cartografia, sinal evidente do seu desconhecimento. (Cf. Santarém - Estudo de Cartografia Antiga, v. II, págs. 237 e segs. Lisboa, 19:10).

(4). - Em que ano teria partido Pedro de Sintra? Antes ou depofis de 1460, ano da morte do Infante? Fontoura da Costa (Descobrimentos maritimas africanos dos portugutueses com $D$. Henrique, $D$. Afonso $V$ e $D$. Joäo $I$, págts. 265 segs. in $I$ Congresso de História da Expensão Portuguêsa no Mundo, 1 a. secção. Lisboa, 1938; $A$ atividade dos descobrimentas desde a morte de $D$. Henrique até ao advento de $D$. Jẫo $1 I$, págs. 357 e segs. in História da Expansão Portugutêsa no Mundo, v. I, Lisboa, 1937) dá a viagemi realizada em 14601461, afirmando que as caravelas do Inflante inegaram até a Serra Leoa. João Barreto (História da Guiné - 1418-1918, pág. 56. Lisboa 1939), aponta o ano de 1462, portanta após a morte de $D$. Henrique -13 de novembro de 1460. Ralph Delgado (História de Angola, v. I, pág. 45. Benguela, 1948), acha que a Serra Leoa foi descoberta pelos navegadores do Ithfante. J. Cortesão ( $O$ /designio do Infante o as explotações atlânticas até a sua morte, pág. 382, in Fistória de Portugal, t. III. Barcelos, 1931) afirma que os capitäes henriquinos ultrapassaram a Serra Leoa, reconhecendo, inclusive, o Gôlfo da Guiné. A esta idéia opõem-6e Duarte Leite (Coisas de Vária História, pág. 49. Lisboa, 1941; Àcerca da Crónica dos feitos da Guiné, págs. 248 e segs. Lisboal, 1941) e Damião Peres ( História dos descobritmentos portuguêses, pág. 116. Pôrto, 1943) que afirmam ter vido o descobrimento do Gôlfo da Guiné realizado pelos navegâdores de Fernão Gomes, já na época de Afonso V. Quanto ao ano da viagem, Damião Peres acha que Pedro de Sintra teria partido em 1461 ou 1462. Ao darmos créllito às narrativas de Cadamosto (Viagens, P. I, págs. 74 e segs.; P. II, págs. 178 e segs.) e Duarte Paxheco (Esmeraldo. L. I, cap. 33, pág. 57), Pedro de Sintra, ainda em vida do Infante, teria faito o reconhecimento d'a costa africana desde a foz do Geba até à Serra Leoa. Em ulterior vilagem, já ao tempo de Afonso $V$, possivelmente em 1461 , teria continuado a navegar para o sul, chegando até a Mata de Santa Maria. Teritam, pois, 7 sido duas as viagens: a primeira a mando do Infante; a segunda, de iniciativa de Afonso V. Numa, chegou às fronteiras da Serra Leoa; noutra, ultrapassou o Cabo Mesurado indo até à Mata de Santa Maria .

(5) . - Assim denominada por Pedro de Sintra, "por ser huuma terra aspera e braua" (Esmeraldo, L. I, oap. 33, pág. 57). 
Partiu de Lisboa possivelmente em 1461, com duas caravelas (6) armadas pela Corôa (7)

Nessa viagem teria reconhecido a costa africana desde o estuário do Geba até à Mata de Santa Maria - extenso e fechado arvoredo situado cêrca de 20 quilômetros para o sul do Cabo Mesurado e já, como êste, em território da atual república da Libéria, ultrapassando, assim, a Serra Leoa (8) .

Cadamosto descreveu a viagem (9). Pedro de Sintra, ultrapassando o trecho acidentado da Serra Leoa, entrou numa costa baixa, de excelentes praias (10), até encontrar um gôlfo, onde desagua o Rio Santa Maria das Neves, repleto de bancos de areia (Ilha dos Bancos). Navegando sempre em direção ao sul, achou outro rio a que chamou Rio das Palmas, pelas muitas palmeiras que cresciam nas suas margens (11). Mais adiante descobriu o Cabo Mesurado. Finalmente, costeando 16 milhas além, chegou ao Bosque (Mata) de Santa Maria, "terminus" da viagem (12).

Pedro de Sintra colheu preciosas achegas para o estudo das condições geográficas da costa (13) e culturais dos indígenas, ao mesmo tempo que procurou saber das possibilidades comerciais da terra. O que mais o maravilhou foi a abundância de ouro que os negros traziam nas orelhas, nos narizes, nos lábios e ao pescoço (14).

(6). - Cadiamosto (Viagens. P. I, pág. 74) afirma que foram duas caravelas. Barros (Dœc. I, L. II, cap. II, pág. 72) aceita o informe, associando à emprêsa a nome de Soeiro da Costa, que seria o capitão de um dos navios.

(7). - Cadamosto (Ibidem) atribui a Afonso $\mathrm{V}$ a inidiativa, da viagem: "el re de portogallo ge manda da poi la morte del dito signor Infante $2 /$ caravelle armada capitanio um juro de sinzia scudel del dito signor re".

(8). - Damiäo Peres (op. cit., pág. 143) nota que Pedro de Sintra, navegando além do Cabo Mesurado, penetrou na zona das calmas equatoriais, sendb, assim, - primeiro europeu a tomar conhecimento dos obstáculos naturais que ali encontra a navegação à vela.

(9). - A vjagem de Pedro de Sintra foi narrada a Cadamosto por um seu antigo éscrivão qưe fêz parte da emprêsa. E' êle próprio que o diz. (Cf. Viałens, P. I, pág. 74).

(10). - "Passada la costa dela montagna liona tuto de in avanti sie terra bassa spiaze com molte seche de arena che eusi fuori in mar" (Ibilfem, pág. 77).

(11). - As árvores, como já o notou M. C. Batista de Lima (O primeiro contacto entre os portuğurêses e os pretos da Guiné, pág. 23, in I Congresso Comemorativo do $V$ Centenário do Descobrimento da Gutiné, v. II, Lisboh, 1946), constituiram importante fator de identificação geográfica. Serviam de padröes, onde se gravavam as armas dos empreendedores, marcandio-se, assim, os têrmos dos descobrimentos a a respectiva posse em nome do rei do Portugal

(12). - Cf. Cadamosto, P. I, págs. 77 e segs.; P. II, págs. 174 e segs.

(13). - A viagem de Pedro de Sintra deu enorme contribuição à cartografia da época. A narrativa de Cadamosto possibilitou aos cartógrafos italianos emendiar certos erros e fazer alguns acrescontamentos, como já o notou $\mathrm{Ch}$. de La Roncière (La découverte de I'Afrique au moyen âge, t. II, pág. 61. Cairo, 1925).

(14). - Cf. Cadlamosto, P. I. pág. 76; P. II, pág. 175 . 
Essa viagem descortinou a Portugal novos e prometedores horizontes. Ninguém mais punha em dúvida a existência de ouro na "Terra dos Negros", que podia ser transportado por via atlântica até ao reino. $\mathrm{Na}$ Guiné, Portugal encontrava, finalmente, o apôio material indispensável à sua própria expansão ultramarina. Ali havia uma imensa riqueza aguardando resgate.

Por isso não admira que as classes mercantis e marítimas do reino, que já estavam entrando numa fase de amadurecimento econômico, adestrando-se para a conquista do Atlântico Sul, se apresentassem como diretas representantes das novas tendências da nação. Todos se mostravam interessados em participar da prometedora emprêsa oceânica. O comércio africano exerceria, fatalmente, sôbre uma burguesia desejosa, uma enorme atração. No "mar tenebroso", os mercadores e marinheiros portuguêses haviam encontrado a fôrça inicial necessária à sua transformação orgânica, de acôrdo com as suas possibilidades sociais e econômicas de expansão.

Morto o Infante D. Henrique, Afonso V mostrou-se logo pouco adestrado para a exploração direta do tráfico africano. A riqueza aurífera era uma realidade. Pedro de Sintra encontrara indígenas "vestidos" com anéis e colares de ouro. Os mais incrédulos mostravam-se, agora, otimistas e esperançosos por deitar a mão ao precioso metal amarelo que se oferecia aos cristãos. Mas o monarca, no entanto, não era muito afeiçoado a empreendimentos dessa natureza. Era quase alérgico a transações mercantis com comunidades tão distantes e enigmáticas. Por isso não admira que, no ano seguinte à viagem de Pedro de Sintra (1462), a Corôa se esquecesse do seu rico patrimônio africano. Precisamente quando a calculista burguesia do reino esperava pelo aceleramento das descobertas e intensificação do tráfico atlântico dá-se nova interrupção. A obsessão da realeza não era a "Terra dos Negros", mas o precipitado assalto a Tânger. O espírito de cavaleiro medieval de Afonso V, inflamado com a conquista de Alcacér-Ceguer (15), sonhava com novos empreendimentos militares em Marrocos.

(15). - Cf. Pina, Rui de - Chronica d'El Rey $D$. Affonso $V$, in Colfecção de Livros Inéditos de História Portugunesa dos reinados de D. Joào $I, D$. Duarte, D. Affonso $V$ e $D$. João $I I$, t. I, págs. 199 e segs.; Góisł Dámião de Crônica do Príncipe D. Jaäo, cap. $X$, páds. 67 e segs. Coimbra, 1905., Axer zedo, P. de - D. Afonso $V$ e a Ordem da Tôrre e Espada, págs. 37 a segs. Coimbra, 1919; Mascarenhas - História de la Ciudad de Ceuta. Manuscrito de 1648 publicado pela Academia das Ciênctas de Lisboa, kap. 58, págs. 232 e segs. Lisboa, 1918. 
Em novembro de 1463, partiu de Lisboa uma fôrça expedicionária com o rei e seu irmão, o Infante D. Fernando. O objetivo era o escalamento de Tânger. $O$ plano de conquista malogrou inteiramente. Depois de Tânger, o nervoso monarca pensou em Arzila. Em agôsto de 1471, a armada real portuguêsa ancorava diante da desejada cidade marroquina. Horas depois os cristãos estavam senhores da situação. À queda de Arzila seguiu-se a de Tânger - fato conhecido.

Mercê dêsse aventurismo oneroso e de certa maneira inútil, apesar de honroso, o tráfico africano foi relegado para um plano secundário. Perseguido pela miragem marroquina, bo soberano deixou-se levar pelo seu fervor cristão e medieval, consumindo boa parte dos resgastes do ouro sudanês no seu cruzadismo (16). Disso se aproveitou a nobreza, despojando a poupança régia (17).

As contradições internas do reino e as aventuras em Marrocos não permitiram à Corôa explorar, ela mesma, o patrimônio africano. Tratou, no entanto, de evitar o alargamento do hiato nas descobertas, resolvendo o problema por meio de certas modalidades de exploração que lhe parecessem mais convenientes ao seu interêsse e às possibilidades de a servir. Por isso viu-se levada a experimentar nova solução ditada pelas circunstâncias.

À cessão "senhorial" e graciosa da época do Infante (18), a realeza preferiu, agora, a cedência onerosa do comércio africano ao capital particular, arrendando, em 1469, a Fernão Gomes, burguês lisboeta, e curiosa figura de empresário colonial, o tráfico da Guiné (19) .

Essa modalidade de cessão de patrimônio não era nova. A Corôa já tinha experiências de arrendamento de outra natureza. Pensemos no caso das, alfândegas, nas saboarias e nos

\footnotetext{
(16). - Para as despesas do seu militarismo senhorial, Afonso $\mathbf{v}$ havia mandado cunhar, em 1457, o cruzado, moeda de ouro. (Cf. Aragão, A. C. Teíxeira de - Descrição cenal e histórica das moedas cumhadas em nome dos reis, regentes e governadores de Portugal, t. I, págs. 223 e segs. Lisboa, 1874).

(17), - Cf. Ribeirol, A. - Afonso-o-Africano, in História de Portugal, v. III, págs. 101 e segs. Barcelos, 1931; Lopes David - A expansão em Marrocos, in História da Expansão Portugúuêsa no Mưndo, v. I, págs. 143 e segs. Lisboa, 1937; França, E. O. - O poder neal em Portungal e as origens do abstalutisrrło, págs. 301 e segs. São Paulo, 1946.

(18). - Veja-se a Carta Régia de 22 de outubro der 1443, lem virtude da qual ninguém poderia ir além do Bojador sem a lioença ou mandado do Infante $D$. Henrique, sob pena da perda dos navios e respectivas cargas (A. N. T. T. Chanc. de D. Afonso V, L. 24, fl. 61; A. D. A. N. T. T., págs. 8 e segs.).

(19). - Cf. Barros - Déc. I, L. II, cap. II, pág. 72.
} 
impostos (20). A transferência da exploração do patrimônio ultramarino seria, assim, um processo de extensão de uma prática régia medieval.

A concessão a Fernão Gomes era um estímulo ao capital particular. O empresário lisboeta já era 'pessoa conhecida e achegada ao trono. Era - é preciso dizê-lo - credor do rei. Já em 1458, por ocasião da conquista de Alcácer-Ceguer, o ricaço de Lisboa fizera certos adiantamentos à Corôa. Mais tarde, quando se deu o assalto a Arzila e Tânger (1471), o abastado empresário colonial, já usufrutuário do trafico africano, abriu, novamente, seus bolsos ao aventurismo afonsino. Ademais, emprestara à realeza certas somas destinadas à deficitária praça de Ceuta (21). O perspicaz burguês, ao mesmo tempo que enriquecia o seu patrimônio, tornava-se um dos favoritos do trono que não teve dúvidas em armá-lo cavaleiro por ocasião do assalto a Tânger (22), prêmio à moda da Reconquista (23).

A cedência fôra feita, no entanto, com a maior cautela. O arrendamento da exploração do tráfico africano foi delegado mediante a expressa condição do empresário-concessionário prosseguir nas descobertas geográficas. O arrendatário comprometia-se a explorar, em cada ano, 100 léguas de costa a partir do Bosque de Santa Maria, têrmo da viagem de Pedro de Sintra e Soeiro da Costa. Outrossim, devia pagar à Corôa a importância de 200 mil réis anuais (24).

Essa solução régia, em que se defendiam os interêsses do Estado, beneficiado pelas enormes vantagens advindas das novas descobertas geográficas e conseqüentes organizações mercantis, ficou assente no contrato de novembro de 1469 (25). O acôrdo (26) era válido por 5 anos. O concessionário ficava

(20). - Cf. Braamcamp Freire - Tombo da Comarca da Beira (1395), in A. H. P. t. X, págs. 209 e segs. Lisboa, 1916; Lencastré, F. de - Tratado das AIfândegas em Portugal, t. I, págs. 163 e segs. Likboal, 1886; Azevedo, Pedro de - Documentos das Chancelarias Reais Anteriores a 1531 Relativos a Marrocos, t. I, Doc. XIII, págs. 18 e segs. Lisboa, 1915; Brito, Pe. Cunha Os pergaminhos da Câmana de Ponte de Ltmấ in Archeóloǵo Portugluêts, v. XIII, págs. 51 e segs.; Marques, J. da Silva - Descobrimentos portuguếses. Documentos para a sua história, v. I, Doc. 63, págs. 64 e segs. Lisboa, 1944.

(21). - Cf Barros — Déc. I, L. II; dap. II, pág. 72.

(22). - Ibidem.

(23). - Com as descobertas e conquistas, inúmeros criados, escudeiros e mercadores foram armados cavaleiros - decorrência das iniciativas bélico-geográficas. Na emprêsa attântica, elementos saídos dias classes populares encontraram um meio de ascensão social.

(24). - Cf. Barros — Déc. I, L. II, Cap. II, págs. 71 e segs.

(25). - Ibriem.

(26). - Ignora-se o texto do contrato. Onde estará guardada? Em urquivo público ou particular? Ou teria levado descaminho? Infelizmente, a ínica fonte conhecida é a narrativa do cronista Barros. 
senhor do monopólio do comércio e navegação em tôda a "Costa dos Negros" já descoberta e por descobrir, com exclusão de duas zonas econômicas: uma ao norte, compreendendo a área geográfica explorada pelos marinheiros e mercadores que traficavam nos estabelecimentos de Arguim, cuja posse exclusiva o favor régio havia concedido ao príncipe D. João (27); outra ao isul, abrangendo a terra firme defronte das ilhas de Cabo Verde, pertencente ao Infante D. Fernando, cuja exploração mercantil estava reservada aos colonizadores das respectivas ilhas (28) . O empresário arrendatário ficava, igualmente, proibido de resgatar marfim, cujo comércio era monopólio do rei (29).

A cessão onerosa a Fernão Gomes era, pois, de enorme interêsse para a Corôa. Eram, assim, os capitais particulares investidos da dispendiosa e arriscada função descobridora de uma longa e enigmática costa do ocidente africano além do Cabo Mesurado e do rio Soeiro. Os riscos e incertezas seriam do arrendatário, não do Estado. Ademais, a cedência era limitada, o que evidencia a solicitude da Corôa, apesar dos pesares, pelas coisas da Guiné. Além da renda certa e direta oriunda da concessão do tráfico, a realeza não abdicou do direito de amealhar outros benefícios do seu rico patrimônio ultramarino.

Não só a cessão era restringida pela interferência estatal, mas, também, todo e qualquer privilégio de comércio com a "Terra dos Negros" obtido por particulares. Tal era, nesse sentido, a regulamentação régia, que Afonso $\mathrm{V}$, logo no ano imediato ao acôrdo com Fernão Gomes, chamou a si, por Carta datada de Alenquer a 19 de outubro de 1470, o monopólio de gatos de algália, pedras preciosas, tintas (brasil e laca), unicórnio (espécie de rinoceronte), malagueta e demais especiarias africanas (30).

Nos cinco anos que se seguiram a 1469 , ano do arrendamento do tráfico, o concessionário Fernão Gomes promoveu, em obediência ao tratado com a Corôa, o descobrimento do Gôlfo da Guiné (31). No cumprimento de sua obrigação de descobrir novas terras africanas, o perspicaz empresário colo-

\footnotetext{
(27). - $\operatorname{Em~1469,~ano~do~acôrdo,~os~resghates~de~Arguim~pertenciam~ao~príncipe~}$ D. João, fillho de Afonso V. Mas pouco depois, o esperto empresário colonial obteve do futuro monarca o monopólio do trato de Arguim, ao preço de 100 mil réis. (Cf. Barros $\longrightarrow$ Déc. I, L. II, Cap. $I_{b}$ pág. 72).

(28). - A.N.T.T. L. das Ihas, fl. 2 v.

(29). - Cf. Barros - Déc. I, L. II, cap. II, pág. 72.

(30). - A.N.T.T. Chanc. de D. Afonso V, L. 21 f fl. 56; A.D.A.N.T.T., pág. 33.

(31). - Já ficou dito que J. Cortesão (cf. nota 4) acha que o Gôlfo da Guiná fờ descoberto na época do Infante, o que se nos afigura inaceitável.
} 
nial equipou, em 1470, uma-caravela cujo comando entregou a Soeiro da Costa, companheiro de Pedro de Sintra (32). Navegando além do Cabo das Palmas, descobriu o rio que tem o seu nome, situado à altura do Cabo das Três Pontas e vizinho da aldeia de Axém (33), onde mais tarde se organizou o trato do ouro. Em janeiro do ano seguinte, uma nova expedição financiada por Fernão Gomes partiu com destino à Guiné. Comandavam-na João de Santarém e Pero Escobar, cavaleiros da Casa del-Rei (34), os quais levavam como pilotos Martim Fernandes e Alvaro Esteves (35).

Navegando em águas da Costa da Malagueta passaram o Cabo das Palmas e o Cabo das Três Pontas, descobrindo a importante aldeia de Samá (36), na embocadura do pequeno rio São João (37), onde organizaram com os indígenas os primeiros resgates do ouro (38).

Prosseguindo na sua viagem para o sul, já na costa setentrional do Gôlfo da Guiné, chegaram ao aldeiamento das Duas Partes, onde Diogo de Azambuja haveria de construir o célebre Castelo de São Jorge da Mina, em 1482, a mando de D. João II (39) .

(32). - A viagem de Soeiro da Costa tem sido omitida pela maioria dos historiadores dos descobrimlentas. Damiắo Peres (op. cith). não a incluti nas expedições promovidas por Fernão Gomes; João Barreto (op. cit.) não a menciona. Ralph Delgado (op. cit.) não the presta atenção. Estramhamos o fato, pois o cronista Barros alude à viagem (cf. Déc. I, L. II, ca.p. II, pág. 72).

(33). - Em Axém foi construída mais tarde, já no reinado de D. Joáo IK uma fortaleza e organizada uma feitoria comercial - adendo da Mina.

(34). - O fato do comando da expedição ser entregue a dàvaleiros do rei não significa nada? Seriam agentés da Corôa associados ao arrendatário? Iriam como funcionários régios ou como simples capitães de. Fernão Gomes? Os novos descobrimentos promovidos pelo concessionário seriam de inteira confiança do monarca? Afonso V não teria nos seus cavaleiros agentes de ligação? Eis o problema que se póe.

(35). - Cf. Barros, loc. ait.

(36). - A atual Shama bay, no entender de Fontoura da Costa ( $A$ atividiade, pág. 359; Descobrimentos, pág. 25) e Damião Peres (op. cuít., pág. 146).

(37). - Prah river (Ibidem - Fontoura da Costa).

(38). - Cf. Barros - loc. cit.; Esmeraldo - L. II, oap. IV, pág. 68.

(39). - Santarém e Escobar organizaram os resgates do ouro nas aldeia megras de Samá e Duas Partes. Exato. Mas qual delas é a Mina? Fontoura da Costa (Descobrimentos, pág. 25) e R. Delgado ( op. cit., pág. 48! afirmam que a Samá deram o nome de Mina. Damiāo Peres (op. cit., pág 147) parece aceitar a explicação, pois escreve: "e a Mina de ouro de Siamá por êles descoberta 1471". Estranhamos o fato dêsses historiadores terem omitido a aldeia das Duas Partes nos descobrimentos promovidos por Fernão Gomes. Terliam sido levados pela narrativa de Duarte Pacheoo (embora não a mencionem) para o qual Samá é a Mina. Pachecó escrevo: "este Rio Sam Johan he muito pequeno e aqui estaa hum luguar que se chama Saramá - qual luguar se fez ho resgate do ouro e quy noiste tempo (escreve em 1505) se chamaa a Mina" (Esmeraldo, L. II, 'cap. IV́, pág. 68). Uima pasagern do cronista Barros leva-nos, no entanto, a conjecturar que a aldeia das Dulás Partes é que seria a Mina. Referindo-se a Samá apenas escreve: "o primeiro resgate do ouro que se fêz nesta terra foi em ua aldea 
O contrato com Fernão Gomes, sendo válido por cinco anos, ia até 1473. Mas o calculista empresário obteve do favor régio, pelo diploma de $1 .^{\circ}$ de junho de 1473 (40), a prorrogação do monopólio do tráfico africano por mais um ano, nas mesmas condições do acôrdo anterior (41). Outrossim, conseguiu de Afonso $\mathrm{V}$ a exclusividade do comércio da malagueta, comprometendo-se, por isso, a pagar à Corôa mais 100 mil réis anuais (42).

Repare-se que a realeza percebia apenas a renda estipulada no diploma contratual. Nada mais. E isto obriga-nos a perguntar o que aconteceu ao quinto durante a vigência do acôrdo. Quer-nos parecer que com a morte do Infante D. Henrique, em 1460, retornou ao Estado, senhor do patrimônio. E isto põe outro curioso problema: com o arrendamento do comércio da Guiné, sôbre quem recaem as despesas militares? Quem as tiver, deverá ter o quinto. Salvo prova em contrário, afigura-se-nos que a Corôa, ao mesmo tempo que arcava com os gastos advindos da defesa militar do patrimônio africano, amealhava o quinto (43).

chamada Stama". Mais adiante, aludindo à Aldè a das Duas Partes: "e depois se fêz mais abaixo onde ora está a fortaleza que el-Rei Dom João mandou fazer, o qual lugar se chamava pelos nossos Aldea das Duas Partes". (Déc. I, L. II, ckp. II, pág. 72).

Concluindo: Samá, ao fundo da atual Shama bay, seria o primeiro loar1 onde os navegadores de Fernão Gomes organizaram o resgate do ouro. No entanto, o centro fundamental do trato do precioso metal amarelo teria sido mudado para Duas Partes (possivelmente a atual Elmira bay), 1ocal mais apropritzdo, onde Azambuja edificou o Castelo de São Jorge. Como - grosso dos resgates do ouro se fazia ali, a região passaria a ser konhecida pelo nome de Mina. E' o que se nos afigtura mais aceitável. Santiarém (Estudos de cartogrifia antiga) nada esclarece. Trata-se de mais um problema de geografia histórick de difícil sollução.

(40). - A.N.T.T. Chanc. de D. Afonso V, L. 33, fl. 147 v.

(41). - "e esto adsy e per aquella maneira e cousas com que tho teemos dado e outorgado na carta do contrauto que dos dictos cinquo annos teem" (Ibidem).

(42). - "e os cem mill reais que despoys se nos obrigbu pella malagueta que mandamos que outrem nos dictos contrautos nom resgate, salvo elle dicto Fernam Gomez" (Ibidem).

(43) . - o "quinto", a rigor, era sôbre prêsas de guerra. Cơm a expansão, a Corôa congerviou essa contribuição de caráter militur. Peĺa mencionada Cartia Régia de 22 de outubro de 1443 sabe-se que a Corôa, até então, amealhava êsse impôsto. Note-se esta fassagem: "daqueles a que elle cisy mandizse ou dese liçença thes desemos o direito do quinto do que de la trousesem, segundo a nos pertençece". (A.N.T.T. Chanc. de D. Afonso V, L. 24, f1. 61; A.D.A.N.T.T., pág. 8). Quando se procurou incrementar a colonização do Brasil, com a criação do sistema das capitanias, inscreveu-se $\mathbf{n}_{\mathbf{p}} \mathbf{a b}$ Cartas de Foral a obrigação de pagarem à Corôa um quinto ra produção os eventuars exploradores mineircs. Há, poif, uma trínsação do regime para a América portuguêsa (Ibidem, Chanc. de D. João III L. 21, f1. 73, transcrita na íntegra in História da Colonizaçào Portuguêsa do Brasil, v. III, págs. 269 e segs. Pôrto, 1924). 
O arrendatário observou ambos os compromissos - o de 1469 e o de 1473 - deixando descoberta, ao cabo do último contrato (1474), tôda a costa setentrional do Gôlfo da Guiné, inclusive as ilhas e o Cabo de Santa Catarina (44), no hemisfério sul (45). Em seis anos, os capitães de Fernão Gomes descobriram mais de 600 léguas de costa além de diversas ilhas. Findo o prazo, o maneiroso e calculista empresário colonial recebeu foros de nobreza e o apelido "da Mina" (46), com que passou a ser conhecido devido à descoberta dessa rica região do ocidente africano, para onde afluía o grosso do ouro que os negros mineravam nos sertões (47).

Assim conseguiu a realeza, através de empreendimentos particulares, abrir a arriscada e dispendiosa trilha ao longo da misteriosa e agressiva "Costa dos Negros". Graças a isso, Portugal pôde organizar em bases firmes a mais importante rota atlântica do ouro africano, questão vital para o Ocidente europeu - fato novo na história do mundo.

Ultimado o contrato com Fernão Gomes. Afonso V, pela lei de 31 de agôsto de 1474 , chamou a si a exploração do tráfico africano (48).

No entanto, paralelamente às contradições continentais, o comércio ultramarino padecia das conseqüências advindas da rivalidade ibérica. Os resgates do ouro, que os capitães de Fernão Gomes haviam organizado nas aldeias de Axém, Samá e Duas Partes, despertavam nas grandes potências os maiores apetites. O monopólio gerava má vontade de Castela, como

(44). - Cape Saint Catherine.

(45). - Depois de descobrirem Slamá e Durs Partes, ionde principiaram a organizar os résgates do ouro em sóbidłas linhas, os navegadores de Fernão Gomes foram batendo a costa alcancando o Cabo Formoso no delita do Niger. Navegando em direção ao sul, descobriram São Tomie (21 de dęzembro de 1471), Ano Bom ( $1 .^{\circ}$ de janeiro de 1472) e Santo Antão ( 17 de janeiro dêste último ano), mais tarde Tihh do Principe em homenagiem ao futuro rei D. João II. De 1471 a 1473 , Fernando Pó descipbriu os Camarões, encontrando, logo a seguir, a Ilha Formosa. De 1473 a 1474 , durante a prorrogação do acôrdo, Lopo Gonçalves chegou ao rio Gabão e a um cabo a que pôs o seu nome. Ainda a serviço de Fernão Gotróts, Rui Siqueira alcançou ( 25 de novembro de 1474) o Cabo des Santa Catarina “terminus" dos descobrimentos geográficos promovidos pelo mpresário Fernão Gomes. (Cf. Barros - loc. cit.).

(46) , - Na quitação dada a Pero Estaço, "Recebejdor moor dos lex (60) milhoóes" um dos contribuintes foi "Fernan Gomes da Mjna". Vide a relação dos prestamistas dos "milhoees" outorgados nas Côrtes de 1477, em Montemor o Nova, e de $1478 \mathrm{em}$ Santarém (A.N.T.T. Chanc. de D. Afonso V, L. 26, fl. 1; A.H.P., t. IV, págs. 426-438).

(47). - Em reconhecimiento da sua valiasa ação descoobridora, Afonso $v$ ideu-lhe, ainda, novas armas. O seu escudo passou a ter três cabeças de negras rom anéis de ouro nas orelhas e nos narizes e um alar ao pescoço. (Cf. Barros — Déc. I, L. II, cap. II, pág. 73).

(48). - A.N.T.T. M. 1.0 de Leis, n屯 718; A.D.A.N.T.T., pág. 40. 
já o notou La Roncière (49). A luta pela partilha econômica e política do Atlântico era um prolongamento das rivalidades internacionais. A fama do ouro da Guiné fazia crescer a excitação dos Reis Católicos. A hostilidade luso-castelhana começava a estender-se à Africa. As riquezas da "Terra dos Negros" constituiam ambionada prêsa. Já em 1475 , ano em que Afonso V invadiu Castela, os monarcas espanhóis enviaram à Costa da Guiné alguns navios com propósitos mercantis (50). Nesse mesmo ano, um pilôto castelhano foi à Mina num barco flamengo, onde realizou algumas transações com os indígenas. Foi, porém, infeliz, naufragando na torna-viagem à altura da Praia dos Escravos (51).

O exemplo de Castela foi logo seguido por outras potências. A crescente fama dos resgates da Mina levou os inglêses a tentar fortuna no "Eldorado" africano. Em 1481, uma frota de mercadores da Inglaterra, já equipada e pronta para partir com destino ao Gôlfo da Guiné, foi embargada pelo rei Eduardo IV, temeroso de quebrar a boa ordem anglo-lusa (52). A par disso, as cobiças, igualmente progressivas, de outros estrangeiros geravam as maiores intranqüilidades nas rotas atlânticas de Arguim e da Mina.

Em 1479, Portugal e Castela, esgotados numa campanha militar desastrosa e inútil, desejam a paz. Em março do ano seguinte, o tratado de Toledo punha fim à guerra (53) .

Graças à amadurecida interferência do príncipe D. João, estabeleceu-se entre as duas potências ibéricas, entre outras cláusulas, que o tráfico africano seria apenas de Portugal (54). De igual modo ficavam aos Reis Católicos e seus sucessores as Canárias (55). Afonso V, apesar dos contratempos de Toro, saía, assim, graças à sagacidade de seu filho, vitorioso da amadurecida luta diplomática. Portugal, embora não conseguisse realizar o seu sonho ibérico, passou a ter, por múltiplas razões, destacada e merecida projeção no quadro das relações internacionais.

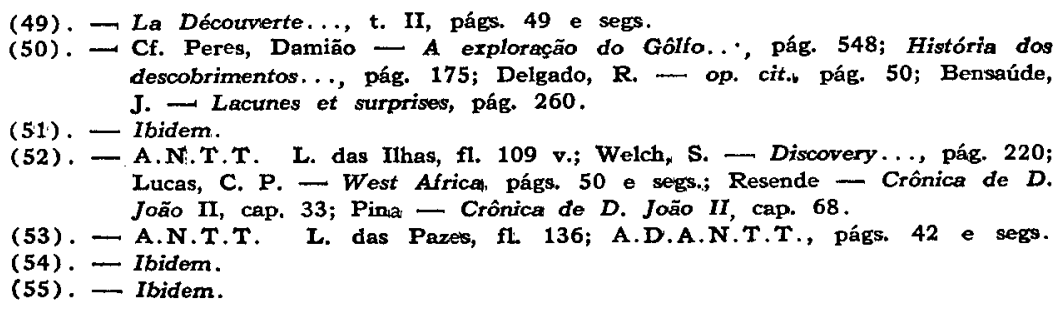


Pouco depois, dadas as conhecidas contradições do "aventurismo" afonsino e da aristocracia agrária e militarista (56), o "generoso" soberano, pela Carta Régia dada em Tôrres Novas a 4 de maio de 1481 , concedeu a seu filho, D. João, a exploração graciosa do monopólio dos "trautos da Guinee" (57).

A "cedência senhorial" de patrimônio seria, quer-nos parecer, uma decorrência dos serviços prestados ao Estado pelo príncipe durante a guerra com Castela. Essa nova experiência régia de exploração do tráfico africano teve capital importância para o destino marítimo de Portugal. O rei entregava ao futuro "Príncipe Perfeito" (58) o comando geral da expansão ultramarina. D. João era, não há dúvida, o mais fiel intérprete do pensamento das avançadas classes econômicas do reino, imensamente interessadas na conquista atlântica. $O$ esperançoso príncipe manifestou logo aptidões de grande estadista e decidido animador dos descobrimentos geo-econômicos, iniciando, assim, a sua gloriosa carreira como orientador da expansão oceânica. Repetia-se, grosso modo, o ato do Regente $\mathrm{D}$. Pedro que entregara os destinos do tráfico africano a seu irmão D. Henrique - etapas experimentais do regime de exploração do rico patrimônio ultramarino.

No mês seguinte (21 de junho de 1481), a bula de Xisto IV confirmou a cessão senhorial do exclusivismo do comércio africano (59) - colaboração da Santa Sé no plano internacional para a mantença do monopólio do trato da Guiné (60).

(56). - Ao deficitário imperialismo senhorial e guerreiro em Marrocos que até a ocupação de Tânger, em setembro đe 1471\} ocupara o espírito do anacrônico monarca, sucedeu a desastrosa polítlca ibérica em que as atenções da Corôa prendem-se ao problema da sucessão ao trono espanhol. (Cf. Ribeiro, A. - A sucoessão de Castela, págs. 115 e segs., in História de Portulfal, v. III, Barcelos, Toro, págs. 134 e segs, ibidem; Afonso $V$ e Lứs VI. As terçarias de Mourla, págs. 148 e 'segs., ibidem; O. Martins - O Principe Perfeito, págs. 209 e segs. Lisboa, 1915; Pina - Crônica de Afonso V, cap. CLXXII; Góis - Crônica do Príncipe D. Jaáo, capł XLII; Resende Crônica de D. João II, cap. VIII; Mendonça, A, Lopes de - A batalha de Toro, in Annaes das Sciencias e Lettras, to I, págs. 701 e segs. Lłsboa, 1857; Santarém - Qưadro, t. III, págs. 1112 e segs.; Viterba, Sousa - A batalha de Toural, Lisboa, 1900.

(57) . - A.N.T.T. Chanc. de D. Afonso V, L. 26, fl. 102 v.; A.D.A.N.T.T, pág. 46.

(58). - D. João tinha, então, apenas 26 anos de idade, pois nasceu em Litboa a 3 de maio de 1455. (Cf. Resende - Crônzica de D. Jaão II, cap. I; Pina Crônica de D. Afonso $V$, cap. CXXXIV; Crôniolp do Príncipe, çap. I) .

(59). - A.N.T.T. Col. de Bulas, M. 35, n. $0^{\circ}$. Esta bula, escrita em latim, acha-se transcrita in A.D.A.N.T.T., págs. 47-55.

(60). - Não obstante exercerem de fato todos os privilégios de soberania póbre a costa africana, nem o príncipe nem o rei se julgavám no direito de anexar novos territórios sem que o alto poder da Igreja legalizasse as conquistas e as descobertas, conferindo as respectivas posses - princípio de Direito Público adotado pelo Ocidente cristão. 
Semanas depois (1. ${ }^{\circ}$ de setembro), D. João era aclamado rei de Portugal (61).

Novo govêrno, novas diretrizes. O "Príncipe Perfeito" definiu logo o seu programa de ação política de austeridade. Portugal era já uma potência colonial, a única da Europa de então. A Madeira enriquecia as cargas de torna-viagem com açúcar, trigo e vinho; Santa Maria e São Miguel, nos Açores, multiplicavam os seus rebanhos; a Terceira constituía, à maneira das demais ilhas atlânticas, excelente base naval para as caravelas das rotas da Guiné; Pico, Graciosa e São Jorge vinham sendo povoadas por agricultores e marinheiros; as ilhas do $\mathrm{Ca}$ bo Verde já figuravam na cartografia; a costa africana, do Rio do Ouro ao Cabo de Santa Catarina, estava sendo sistemàticamente explorada; os potentados negros dos rios Senegal, Gâmbia e Geba, mostravam-se dispostos a estreitar relações de comércio pacífico com a clientela portuguêsa; os resgates do ouro e dos demais produtos ricos da Guiné animavam o dinamismo mercantil português que crescia em direção do Atlântico Sul, numa necessidade orgânica de expansão. Graças a essa efervescência capitalista, Portugal surgia na história moderna como centro motor da revolução econômica e social do Ocidente.

Com D. João II no trono, tudo retorna à Corôa. Ninguém reclamou o patrimônio ultramarino que, de direito e de fato, pertence ao monarca e cuja delegação pode ser concedida ou não pelo favor régio. E' então que se define o monopólio do Estado - a propriedade do comércio e a exploração direta, sem cedência graciosa ou onerosa a senhorios ou a empresários coloniais. Como o govêrno dos domínios atlânticos e o tráfico estão associados como atributos da Corôa, o militar, o administratrativo e o mercantil não se dissociam mais. Daí a urgente necessidade de se criarem organismos autárquicos de contrôle, de que as Casas de Lisboa e as feitorias híbridas do ultramar constituem expressivos exemplos.

A complexidade crescente das trocas e a interdependência cada vez maior entre as diversas regiões do patrimônio atlântico conduziam, fatalmente, a realeza a um processus de concentração e centralização de capitais, numa autêntica supremacia monopolizadora, preâmbulo da sua autocracia, no plano político, e do seu incipiente capitalismo monárquico, no plano econômico. O monarca, até então chefe e protetor do

(61). - Cf. Auto da Aclamiação in A.N.T.T. Chano. de D. João II, X. II, fl. 1, transcrito in Freire de Oliveira - Elementos..., t. I, págs. 346-353. 
cometimento oceânico, torna-se, agora, o grande empresário colonial.

As investidas de D. João II contra uma nobreza estéril e deficitária (62) encontravam seguro assento financeiro nos empreendimentos africanos que empolgavam o trono e a burguesia, sua aliada. Ninguém melhor do que o novo monarca sabia o que significava o tráfico da Guiné para a obra interna e externa que a Corôa se propunha realizar - centralização do poder político e expansão ultramarina. Decidido a não deixar o comércio africano crescer ao acaso ou em benefício de particulares, a realeza chamou a si o monopólio de exploração. Os informes que os comerciantes e marinheiros portuguêses haviam obtido dos negros da Senegâmbia foram suficientes para sugerir ao príncipe que o tráfico seria mais proveitoso para si nas mãos do Estado. A colaboração mercantil entre negros e cristãos aumentava. Arguim, chave e empório do trato durante meio século, não comportava mais as crescentes exigências da expansão atlântica. Impunha-se a urgente solução do problema com o estabelecimento de novos centros de resgates que mantivessem a contínua corrente de comércio que vinha eletrizando Portugal. Era preciso organizar novas feitorias, garantidas por fortalezas militares, numa área da "Terra dos Negros" mais densamente povoada e econômicamente mais fértil.

Semelhantes razões levavam D. João II a perseverar na marcha para o Atlântico Sul. O novo monarca estava resolvido a encontrar o remédio para o mal que 'afligia a nação. Por isso iniciou uma política que sacudiu o país inteiro. A bravura do "Príncipe Perfeito" "foi uma chispa que quase inflamou o estopim de uma revolução. A sua enérgica e decisiva ação política interrompeu a marcha acelerada da nobreza retrógrada e parasitária que ameaçava atirar o reino para o completo descalabro. A figura do novo soberano tinha, forȩosamente, que emergir da desolação política e administrativa que transformava o trono num cadáver em franca decomposição. O novo govêrno, para salvar a nação desgovernada, lançou mão de tôdas as armas, ensanguentando suas próprias mãos na carne do Duque de Viseu, seu primo e cunhado (63). Outrossim, não hesitou em aplicar o remédio supremo, pren-

(62). - Cf. Franga, E. O. - 0 poder..., págs. 322 e segs.; Ribeiro, A. $\longrightarrow 0$ rei contra a nobreza, págs. 162 e segs., in História de Porturgat. v. III. Barcelos, A.conspiraçāo dos nobres, ibidem, págs. 181 e segs.; $O$ Príncipe Perfeito, Ibidem. págs. 191 e segs.

(63). - Cf. Pina - Crónica de D. João II, cap. XVIII, pág. 59. 
dendo e executando os chefes da nobreza conspiradora, entre êles, o mais vil, o Duque de Bragança (64), três dias antes do Duque de Viseu ser apunhalado em Setúbal.

Desde então ninguém mais se atreveu a conspirar contra a Corôa. D. João II, daí por diante, governou livre e desembaraçado. À medida que centralizava o poder político, fazia novos planos de expansão ultramarina. Senhor.dos resgates do ouro africano resolveu tomar o rumo certo, fazendo com que a emprêsa atlântica se financiasse a si mesma. Chamando a si os "trautos da Guiné" mostrou-se, com isso, resolvido a enfrentar todos os contratempos. Disposto a defender a dourada "Costa dos Negros" das interferências estranhas e tentativas de espoliação, colocou na ordem do dia, em caráter de urgência, o projeto de construção de fortalezas e feitorias no Ocidente africano com o claro intento de garantir a regularidade do tráfico do ambicionado metal amarelo que os negros mineravam no interior ignoto.

A carência de dinheiro era instante. Impunha-se organizar os resgates do ouro na nova área geográfica, densamente humanizada e rica, cuja exploração e reconhecimento haviamı sido iniciados pelos capitães do calculista empresário lisboeta Fernão Gomes. Desde que Rui de Siqueira chegara ao $\mathrm{Ca}-$ bo de Santa Catarina, em 1474, não se tinham efetuado novas viagens de descobrimentos. A guerra com Castela (1475-1479) provocara uma pausa nas navegações. Ultimadas as campanhas militares afonsinas, D. João II, já assente no trono, voltou-se para a expansão oceânica, dando maior impulso e cunho prático ao tráfico africano.

A Mina despertava os maiores apeties. Uma terra onde o ouro se trocava por bugigangas, era demasiada atraente para se deixar crescer ao acaso, ou nas mãos de emprêsas particulares. Para conservar a Guiné aurífera - "Terra da Promissão" - a Corôa tinha de estar atenta, de vigia permanente. A costa dourada da Mina, começada a explorar por Santarém e Escobar, enriquecera o burguês concessionário Fernão Gomes e estava, agora, ameaçada de cair nas garras das mais desordenadas contradições imperialistas das grandes potências.

Por isso D. João II apressou-se a organizar uma fortaleza-mercado - centro fundamental do tráfico - na Mina, para onde seria drenado o ouro do sertão. Ao mesmo tempo, serviria de defesa contra o intruso vindo do mar ou do interior.

(64). - Ibidem cap. XIV, págs. 42 e segs.; A. Ribeiro - A conspiração, págs. 181 e segs. in loc. cit. $O$ rei contra nobreza, págs. 162 e segs., in loc. cit.; França $\longrightarrow O$ poder..., págs. 324 e segs. 
O "Príncipe" estava resolvido a montar em sólidas linhas uma nova zona de "captura". Nesse ponto extremo da costa conhecida é que tinham lugar os grandes resgates do precioso metal amarelo. A penetração continental portuguêsa na Africa Negra iria prender, novamente, e com maior vigor, as atenções da realeza. A ação régia tinha, pois, por incitamento, a prosperidade de um rico tráfico de ouro, origem da vasta organização marítima de D. João II e do considerável desenvolvimento da navegação no Atlântico Sul (65) .

A idéia de construir uma fortaleza-feitoria na costa da Mina era, deveras, audaciosa. Manter uma colônia de exploração numa terra tão distante de Lisboa, e adversa à vida dos europeus, parecia uma utopia, plano aparentemente irrealizável. As condições climatológicas e a franca hostilidade dos indígenas eram problemas difíceis de enfrentar. Por isso não podia esperar-se que uma pequenina guarnição de homens brancos pudesse viver naquelas paragens, tão longe da civilização. Fundar uma colônia cristã no coração da "Terra dos Negros" seria, no entanto, serviço de Deus, ao mesmo tempo que traria honras e proveitos materiais à realeza. Havia, assim, uma convergência de razões que estimulavam o monarca português a levar avante o audacioso empreendimento. Com o trato da Mina, D. João II solucionaria os desassossegos que ameaçavam o prestígio da nação e a autoridade do trono. $O$ ouro da Mina seria a salvação de Portugal e da monarquia politicamente centralizada, de um lado, e, de outro, do resto da Europa Ocidental desmetalizada. A Mina seria, efetivamente, a 'retaguarda econômica do "Príncipe Perfeito", ponto de apôio financeiro do movimento oceânico expansionista em demanda da fndia, que haveria de mudar tão profundamente as perspectivas mundiais.

A segurança e regularidade do trato exigiam o estabelecimento de fortalezas - associação do militar ao mercador. A emprêsa era difícil. Exigia, antes de tudo, um executor de

(65). - Foi enorme a influência l'co ouro africano no progresso geográfico, náutido e científico. As idéias dos homens começavam a expandir-se à medida que os seus espíritos recebiam impressōes das nova's terras descobertas. O golpe dado pela expansão oceânica ao sistema le Ptolomeu, em matéria de geografia, foi tremendo. A cosmologia de Nicolas Koppernigh (Copérnico) nasceria - - o que se nos afigura $\longrightarrow$ da ação atlântica portuguêsa. As novas descobertias deram confirmação às suas especulações, especialmente a respeito da esfericidade da terra. Graças a isso teria podido rejeitar os epiciclos ptolomaicos e propor a conhecida teoria do movimento planetário, exposta em 1545 na cidade de Nuremberg - importante comunidade alemã de estreitał relaçōes com Portugal. (Cf. Welch - Europes Disooveryh pág. 326; Bensaúde - Lacurneg et Surprises, pág. 256). 
singulares aptidões. Não se tratava de uma missão de descoberta ou de conquista. A incumbência era outra. Consistia em escolher na costa da Mina um ponto estratégico, onde se haveria de estabelecer um forte núcleo de colonização, de nítidas feições comerciais e militares, com o claro objetivo de defender a "conquista" e assegurar o tráfico com os reinos negros circunvizinhos, senhores dos segredos das pistas do ouro. $\mathrm{O}$ trato impunha o estabelecimento de bases de ocupação permanente. $O$ plano da realeza consistia em proteger o seu rico patrimônio africano contra a cobiça dos "atravessadores" nacionais e estrangeiros.

Previdente e perspicaz como era, D. João II não queria expor o seu monopólio a riscos inúteis. Com o intento de proteger o comércio da Guiné, cada vez mais lucrativo, organizou uma frota de dez caravelas e duas urcas, cujo comando foi confiado a Diogo de Azambuja (66), com a missão de fundar na Costa da Mina uma fortaleza destinada a garantir, em favor da Corôa, os resgates do ouro. Azambuja ia comandar doze navios até aos confins do mundo descoberto, onde, com o consentimento dos potentados negros, construiria uma fortificação militar e organizaria um entreposto mercantil destinado às trocas. A missão era de paz e comércio. Entre portuguêses e indígenas deviam existir as melhores relações de amizade. Os cristãos chegariam como amigos, não como intrusos hostis. Nada de conquistas violentas, demonstração de fôrça. Paz a todo preço. Paz e bons negócios. Nisso consistia a ação colonial portuguêsa, maneiroso e completo sistema de exploração ultramarina, forma original de colonização.

Amadurecidos os planos no cérebro prodigioso de D. João II, equipada a frota com todo o esmêro, Azambuja fêz-se ao mar. Repare-se que o elevado número de navios demonstra que não se tratava de uma expedição de descoberta, mas, sim, da montagem de um incipiente núcleo colonial, o primeiro que os europeus fundariam no Gôlfo da Guiné.

\footnotetext{
(66). - Azambuja não foi um descobridor, tampouco um conquistador. Foi, ante de tudo, um diplomata. Homem experimentado nas campanhas peninsulares e marroquinas, oferecia ao rei a supa fidelidide e o seu saber. Ninguém melhor talhado do que êle para executar o plano amadurectido no cénebro de D. João II. Cavaleiro da Casa de D. João, e companheiro mär logrado do Infante D. Pedro, Azambuja teve seu nome imortalizado com a fundação do Castelo de São Jorge da Mina. Em recompensa da seus erviços, D. Joăo II, por uma Carta Régilax de 17 de março de 1485, conferiu-the licença para "qua no escudo de suas armas possa mater e meta un castelo além das outras armas suas que tem". (Cf. L. Cordeino Diogo de Azambuja.... in Questões, v. II, págs. 93-174. Lisboa, 1936. ou, in Bol. da Sociedade de Geog. de Lisboa, págst 5 e segs. 1892).
} 
Azambuja partiu de Lisboa no dia 12 de dezembro de 1481 (67), três meses após a aclamação do "Príncipe Perfeito". Com êle seguiram 600 homens -100 artífices (pedreiros, carpinteiros, etc.) e 500 soldados (68). As duas urcas, protegidas por uma caravela de reconhecimento, por serem barcos mais lerdos e pesados, já haviam partido dois dias antes (10 de dezembro de 1481) com enormes quantidades de cal, telhas, pregos, mantimentos, munições, madeira e pedra aparelhadas (69). Todo material de construção destinado à edificação da fortaleza foi pré-fabricado. O cuidado, o primor, o esmêro com que tudo foi preparado, demonstra que o arquitetado plano do rei foi largamente pensado. Tudo devia ir já pronto do reino. $\mathrm{Na}$ enigmática "Terra dos Negros" não encontrariam pedra e cal à mão. Ademais, não convinha perder tempo, numa terra física e humanamente agressiva, preparando materiais de construção .

Navegando em direção ao sul, Azambuja não perdeu tempo em explorar a longa e misteriosa costa da Guiné. Sua missão era outra. Por isso seguiu diretamente para o Cabo das três Pontas, entre o qual e o das Rêdes se estendia a famosa e rica Costa da Mina. Percorrendo o litoral, chegou à aldeia das Duas Partes, onde seria construído o forte militar (70). Ali encontrou João Bernardes, com uma caravela da Corôa, resgatando ouro com os negros vassalos do príncipe Caramansa (71), sinal evidente de que o trato já vinha sendo organizado antes da construção do Castelo de São Jorge.

O primeiro problema que se colocou foi o da escôlha do local. O sítio devia oferecer condições favoráveis. O lugar foi reconhecido com cautela - abundante em água potável, dispondo de uma península baixa e fàcilmente fortificável, tanto do lado de terra como do mar, praias seguras e abrigáveis, permitindo ancoragem fácil e livre de receios. $\mathrm{Na}$ escôlha do local reside a melhor parte da obra de Azambuja. O sítio era o mais estratégico, permitindo a drenagem mercantil de uma vasta área econômica da Guiné. Ficava logo ao sul da zona aurífera, no itinerário do dourado Bambouk, vizinho da aldeia das Duas Partes e de fácil penetração comercial para o entreposto de Samá, onde Santarém e Escobar haviam iniciado o trato com os indígenas. O local era deveras estra-

(67). - Cf. Barros - Déc. I, L. III, cap. I, pág. 78.

(68). - Ibidem.

(69). - Ibidem.

(70). - Ibidem.

(71). - Ibidem. 
tégico, situado na bela baía que se alonga do Cabo das Três Pontas ao Cabo Corse - o atual Cape Coast Castle. Ali os cristãos resgatavam ouro em pó e em jóias nos melhores têrmos. O lugar era excelente para o tráfico com o sertão. Corresponde, grosso modo, às atuais áreas do Achanti, Uangara e Bonducu (72), numa privilegiada trilha de penetração comercial .

Escolhido o local, Azambuja tratou de conquistar a amizade e a confiança dos indígenas. Resolvido a edificar a fortaleza, tratou de negociar o caso com Caramansa, senhor da região. Servindo-se da experiência de João Bernardes, o capitão de D. João II pediu uma entrevista ao príncipe negro, a fim de obter a necessária autorização para construir o forte militar (73). O régulo aquiesceu ao pedido do diplomata português. O cronista Barros (74) descreve a conferência, cujo objetivo foi plenamente atingido (75).

Iniciados os trabalhos, em vinte dias apenas o forte já estava em posição de defesa. Próximo ao castelo, Azambuja mandou construir uma capela dedicada a São Jorge, santo protetor de D. João II (76).

Ultimada a construção da fortaleza (77), famosa sentinela da nova área dos resgates do ouro africano, Azambuja assentou em sólidas linhas o trato com os indígenas. A feitoria da Mina, protegida pelo forte militar, chamou logo a si o grosso do tráfico do ouro sudanês. Os cristãos, fielmente re-

\footnotetext{
(72). - Cf. Welch - Europés Discoveryb pág. 219; Bovil, E. W. - Caravans of the old Sahara, págs. 184 e seg. Londrel, 1933

(73). - Cf. Barros - DÁ T, L. İ, cap. I, pág. 78.

(74). - Ibidem, págs. 79 e segs.

(75). - Antes de ordenar o início da construção do florte militar, Azambujja tomou posse de uma árvore numa elevação próxima à aldeia dals Duas Partes, mandou arvorar a bandeira das quinas reais e erguer um altar onde se celebrou a primeira missa (20 de janeiro de 1482). Barros, Ibidem, pág. 79) coloca a aldeia das Duas Phartes como pertencente à Etiópia - "primeira missa dita naquelas partes da Etiópia". A colocação da Etiópia na Guiné constitui êrro comum na cartografía do tempo. No planlsfério do Diogo Ribeiro de 1527, por exemplo, a Etiópia, terra do Preste João, figura na região da Guiné. (Cf. Carta, in A. Cortesāo - Cartografia..., v. II, Estampa XVII).

(76). - Cf. Barros - Déc. I, L. III, cap. II, pát. 84.

(77). - Nos séculos seguintes, a partilha do Atlântico pelas grandes potências (Holanda, Inglaterra, França, Portugal e Espanha) acarretou enormes sobressaltos ao ultramar português. O Castelo de São Jorge da Mina foi um dos baluartes da resistência. Durante o período da unidade ibérica (15801640), os holandeses assaltaram, por diversas vêzes, o forte construído por Azambuja, até que se apoderaram dêle. Mas, em 1657, graças a Francisco de Brito Freire, vencedor dos holandeses em Pernambucol a Mina escreveu uma bela página da Restauração no ultramar. (Cf. Vasconcelos, Frazāo de - A fortaleza de São Jorge da Mina, slorioso padrão do império, plano para a aura recuperaçäo. Lisboa, 1934).
} 
presentados pelos portuguêses, indo por via atlântica até aos mercadores do precioso metal amarelo, tornaram-se os grandes senhores dos caminhos do ouro novo.

Organizada a defesa da nova colônia militar e mercantil, o maneiroso capitão de D. João II deixou-se ficar na Mina durante dois anos e sete meses (78). Com êle ficaram 60 homens integrantes da guarnição destinada à segurança do incipiente núcleo colonial (79).

O esperto Azambuja escolhera para a sua colônia o melhor local, o mais estratégico ponto da costa para a penetração comercial. A Mina era o sítio mais favorável para a "captura", o lugar mais conveniente para encorajar os nativos do sertão a levar o ouro em pó e em jóias até aos estabelecimentos portuguêses da costa.

Semelhante drenagem aurífera em favor do tráfico Atlântico à distância constitui o coroamento de um longo processus histórico, uma autêntica emprêsa civilizadora em marcha ascendente.

As relações humanas com os régulos do interior foram amigáveis, fato que favoreceu muitíssimo o audacioso empreendimento. A notícia do estabelecimento português na costa espalhou-se ràpidamente pela floresta. $O$ precioso metal amarelo dava fôrças aos europeus para suportar as adversidades climatológicas e os demais perigos que o "Eldorado" negro apresentava.

A Mina completou Arguim, inaugurando, em bases firmes, o sistema ultramarino das feitorias comerciais, onde se encontram associados o militar e o mercador - episódio momentoso na gênese e expansão do mundo moderno. Com isso os portuguêses adiantavam-se aos demais povos europeus, tornando-se os vanguardeiros de um singular sistema de colonização branca na Africa negra.

Com o ouro da Mina, a realeza readquiriu segurança e tranqüilidade financeiras indispensáveis à consolidação da sua autocracia e à organização de novos empreendimentos ultramarinos. Assentes no ambicionado metal fino resgatado na

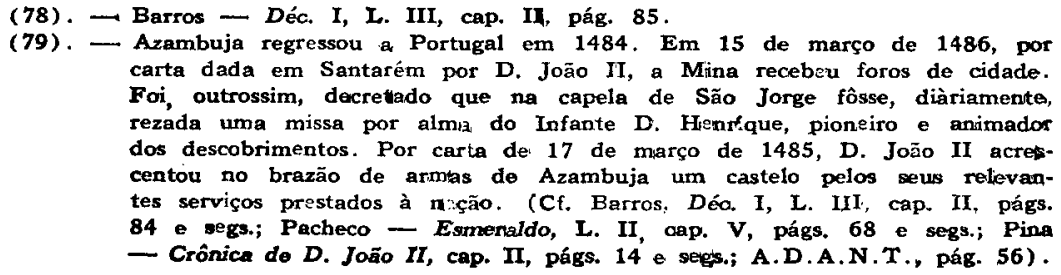
carta dada em Santarém por D. João II, a Mina recebeu foros de cidade. Foi, outrossim, decretado que na capela de São Jorge fôsse, diàriamente, rezada uma missa por almi, do Infante D. Henrque, pioneiro e animador dos descobrimentos. Por carta de 17 de março de 1485, D. João II actescentou no brazão de armas de Azambuja um castelo pelos seus relievantes serviços prestados à nação. (Cf. Barros, Déa. I, L. III, cap. II, págs. 84 e gegs; Pacheco - Esmenaldo, L. II aap. V, págs, 68 e segs.; Pina - Crônica de D. João II, cap. II, págs. 14 e segés.; A.D.A.N.T., pág. 56) . 
costa, puderam os marinheiros e mercadores portuguêses traçar rumo certo e seguro, através da grande e ignota via atlântica, até aos ricos mercados das especiarias asiáticas e dos campos auríferos do enigmático Monomotapa.

\section{OS MECANISMOS DOS RESGATES.}

Junto à costa, no trecho compreendido entre o rio Soeiro e o rio da Volta (80), os feitôres e capitães de D. João II estabeleceram as importantíssimas "sucursais" de comércio de Axém e da Mina, onde os cristãos organizaram os resgates do ouro (81). A Mina tornou-se logo o centro fundamental do tráfico atlântico do metal fino africano, verdadeiro nó dramático da nova realidade econômica do rico patrimônio ultramarino português.

A área do trato, embora alargada até às vizinhanças do Cabo das Palmas, e estendida para além do rio da Volta, junto ao reino negro de Benin, era, no entanto, representada pelos resgates realizados nos aldeiamentos de Axém, próximo ao Cabo das Três Pontas, e de Samá, junto ao Cabo Corse, em cujas redondezas Azambuja construiu o castelo de São Jorge.

Depois da Mina, o grande centro dos resgates do ouro era Axém. Antes de 1505, ano em que Pacheco escrevia, D. Manuel mandou construir nesse ponto da costa da "Terra dos Negros", à maneira do que D. João II fizera na Mina, uma fortaleza militar, sinal evidente do seu valor estratégico e comercial (82). De Axém, a realeza amealhava, anualmente, numa época em que não podemos precisar, mas que é anterior a 1505, 30 a 40 mil dobras de ouro fino, mostra da intensidade dos resgates nessa área do ocidente africano (83).

O castelo de Axém ficava, igualmente, junto à costa, para a parte norte 30 léguas antes do de São Jorge. Nele havia um capitão, comandante do forte, um feitor do rei e alguns homens "de guarda" (84). Em 1505, no reinado de D. Manuel, o trato do Axém, adendo da Mina, era ainda intenso (85).

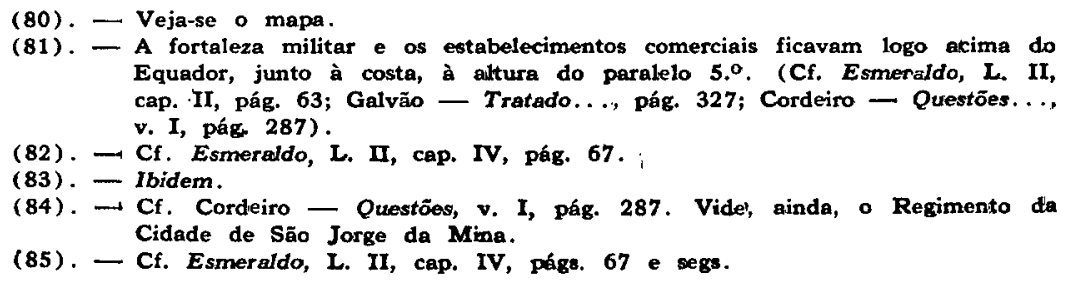
Equador, junto à costa, à altura do paralelo $50^{\circ}$. (Cf. Esmeraldo, L. II, cap. 'II, pág. 63; Galvão — Tratado...., pág. 327; Cordeiro - Questōes.... v. I, pág 287).

(82). - Cf. Esmeraldo, L. U, cap. IV, pág. 67.

(83). Ibidem.

(84). $\rightarrow$ Cf. Cordeiro - Questöes, v. I, pág. 287. Vide', ainda, o Regimento da Cidade de Sāo Jorge da Mina.

(85). - Cf. Esmeraldo, I. II, cap. IV, págs. 67 e segs. 
Do rio Soeiro à Mina, os resgates eram mais lucrativos. Era nesse trecho da costa que ficavam as aldeias de Samá e Duas Partes. A ação comercial portuguêsa, no entanto, não se limitou a essa área geo-econômica. Antes de 1505, os capitães da realeza, possivelmente de D. João II, organizaram adiante da Mina outro importante centro de tráfico - o Cabo das Rêdes, para onde afluía o ouro mais fino resgatado na costa (86).

A feitoria da Mina, porém, concentrava o grosso do trato do ouro. Vejam-se, por exemplo, as procedências dos carregamentos de metal nobre recebidos pelas tesourarias da Casa da Moeda de Lisboa (87). O retôrno de Portugal à efetiva amoedação deve-se, realmente, aos resgates da Mina. Nos anos de 1512 e 1513 , época em que os capitães manuelinos já haviam organizado a rota atlântica das especiarias asiáticas, o tráfico da Mina, se já estava minguado, não tinha, entretanto, desaparecido. Nesse período, a Corôa amealhou dessa "filial" nada menos que 1.629 marcos de ouro, prova evidente da continuidade dos resgates no reinado de D. Manuel (88). Mas não fica nisso o exemplo. Em outubro do ano seguinte (1514), Alvaro Salgado, feitor de D. Manuel em São Jorge da Mina, recebeu de Diogo Aires 21 marcos, 1 onça e 7/8 de ouro "que tinha feito na roupa velha" (89). Outrossim, nos anos de 1517, $1518,1521,1523$ e 1524 , deram entrada na Moeda de Lisboa para serem cunhados, 8.503 marcos de ouro. Dêsse montante, mais de 75 por cento era proveniente dos estabelecimentos da Mina, expressiva mostra da riqueza aurífera dêsse trecho da costa do ocidente africano, ainda nessa altura do século XVI $(90)$.

Ouro, escravos e marfim eram as principais mercadorias que os feitores da Corôa adquiriam aos negros da Mina. O precioso metal amarelo era, no entanto, a maior atração. Como forma de pagamento, as tesourarias da Casa da Mina, em Lisboa, enviavam para os resgates do ouro artigos de cobre e de latão (bacias, manilhas e caldeiras), contas cristalinas, azuis, amarelas e "de muitas sortes", conchas, coral, alambéis, aljarávias, lenços, alquicés, barretes e peças de panos diversos. Com essas mercadorias de procedência européia e afri-

(86). - Ibidem, pág. 70 .

(87). - Vide registros da entrada do ouro no Arquivo da Casa da Moeda de Lisboa.

(88). - A.N.T.T. C.C. P. I, M. 39, Doc. 137 .

(89). - Ibidem, C. Miss. M. I, n.o 55 .

(90). - Vejam-se os registros no Arquivo da Moeda de Lisboa. Pensemos no que representam êsses algarismos, sendo o marco eqüivalente a 232 gramas. 
cana (Marrocos), os feitôres da realeza adquiriam ouro aos indígenas (91).

Os alambéis, as alaquecas e as aljarávias eram artigos importados de Marrocos atlântico e do Mediterrâneo africano. Para isso, a Corôa portuguêsa organizou "sucursais" em Oran (92), Safim (93) e Messa (94), com o claro intento de negociar essas mercadorias indispensáveis aos resgates do ouro do Sudão centro-ocidental. Os artefatos de metal (bacias e manilhas de cobre e latão) eram de origem alemã (95). Constituiam as melhores formas de pagamento do ouro. O cobre, por exemplo, era artigo largamente desejado pelos negros da Guiné. Era matéria prima muito procurada pelo incipiente artezanato indígena. Empregado em múltiplos usos e adornos (manilhas, bacios, bacias, caldeiras, etc.), êsse metal alemão era, depois do sal, a mercadoria que os nativos mais estimavam (96).

Em época anterior à organização portuguêsa das rotas atlânticas do ouro africano, os negros do Sudão recebiam cobre do Suz, a grande área econômica do hinterland marroquino, e dos entrepostos do Mediterrâneo africano, onde traficavam os mercadores italianos, fielmente representados pelos espertos genoveses e venezianos (97).

As contas cristalinas e coloridas eram, igualmente, oriundas da Alemanha do Sul - Nuremberg e Augsburgo. Antuérpia, privilegiado pôrto da Europa onde D. Madnuel montou a famosa sucursal da Casa da fndia, era a grande praça reexportadora. Graças a êsse trânsito atlântico pôde a Alemanha dos metais, senhora das minas de cobre argentífero da Boêmia, do Tirol e da Hungria, chamar a si, por ocasião do em-

(91). - Os livros das chancelaries, guardados no Arquivo Nacionkal da Tôrre do Tombo, em Lisboa, ministram preciosas achegas para um iestudo dessa natureza. Vejam-se, outrossim, as Cartas de Quitzção de D. Manuel, publicadas por Braamcamp no Arquivo Histórico Portưguês.

(92). - A.N.T.T. Chanc, de D. Manue1, L. VI, fll 8; L. Jas Ilhas, f1. $\mathbf{3 2}$.

(93). - Ibidem; Ibidem, ft. 33.

(94). - Figanier, J. - História de Santa Cruz du Cabo de Gué, pág. 29, Lioboa, 1945 .

(95). - Vejam-se as mencionadas quitações de D. Manuel e as chancelarias guardadas no A.N.T.T

(96). - Cf. Bovil, E. W. - Caravans of the old Sahara, pags. 100 e segs.; Pianel, G. - Les preliminaires de la conquête du Soưdan per Mouläy Ahmad al-Mainsur, in Héspéris, t. XL, $10^{\circ}$ e $20^{\circ}$ trimestres, págs. 185 e segs. Paris, 1953.

(97). - Cf. Labouret, M. - Histoires des noirs d'Afrique, págs. 144 e segs. Paris, 1946; Ricard, R. - Contribution là l'étude du Commerce énois au Maroc durant la période portugaise (1415-1550), in Annales de PInstiturt d'Etudes Orientales de la Facuité des Lettres d'Alger, v. III, págs. 53 e segs. Arge1, 1937; Etudes sur Phistoire des portugatis au Maroc, págs. 115 e segs. Coimbra, 1955; Figanier - op. cit., pág. 33. 
preendimento oceânico português, a primazia desfrutada, até então, no quadro das relaçōes internacionais, pela Alemanha do Báltico. Essa reciprocidade de natureza econômica entre Portugal e as cidades alemãs de Nuremberg e Augsburgo contribuiu, enormemente, para a política manuelina de aproximação da Casa da Austria. O estreitamento de relações comerciais com Antuérpia e a Alemanha caminhou paralelo com a expansão atlântica portuguêsa. A metalurgia e a mineração alemãs puderam desenvolver-se pela necessidade crescente que os centros de permutação ultramarina na "Terra dos Negros" tinham de metais - cobre e latão. Repare-se, pois, nessa reciprocidade de favores mercantis, e compreenderemos melhor a participação alemã na gigantesca emprêsa atlântica.

Os panos que entravam nos resgates do ouro eram de origem flamenga e africana. As quitações de D. Manuel mencionam a importação de téxteis flamengos. O autor do Esmeraldo, por sua vez, alude aos panos vermelhos, azuis e brancos, fabricados em Oran e Tunes, pondo-os no grupo de mercadorias de maior aceitação comercial na "Terra dos Negros", especialmente na Mina (98).

Nos estabelecimentos da costa e nas aldeias do interior, os cristãos adquiriam o precioso metal amarelo a trôco dessas mercadorias procedentes da Flandres, da Alemanha do Sul e da Africa do Norte. Manilhas de latão e cobre, panos vermelhos, lenços e bacias eram as melhores formas de pagamento. Quando não resgatavam na feitoria, os portuguêses subiam os rios em pequenos navios abarrotados dêsses artigos, com os quais adquiriam ouro e escravos aos régulos dos sertões (99).

Além da Mina e de Axém, os oficiais da Corôa organizaram o trato no Cabo das Rêdes, ao sul do Cabo Corse (100), onde era resgatado o ouro mais fino da "Terra dos Negros". Dêsse centro de permutação, D. Manuel amealhava, em 1505, 10 a 12 mil dobras de ouro "das quaees as sinco a seis mil dellas he de vinte e tres quilates em fineza hum quilate mais fino em ley que o que os mercadores vaão resguatar na Mina" (101).

Ao sul do rio da Volta ficava o reino de Benin, principal mercado fornecedor de escravos. Ali não havia ouro, apenas a ambicionada mercadoria humana e uma procurada e comer-

(98). - Esmeraldo, L. II, cap. IV, pág. 67.

(99). - Ibidem, cap. I, pág. 60 .

(100). - Vide mapa.

(101). - Cf. Esmeralda L. II, cap. VI, pág. 70. 
ciável especiaria africana - a pimenta de rabo, que os portuguêses resgatavam com manilhas de latão (102) .

No comêço do século XVI partiam anualmente de Lisboa 12 navios, armados pela realeza, com carga destinada ao trato da Mina. Na torna-viagem transportavam para a capital portuguêsa o ouro resgatado pelos feitôres do rei (103) .

D. Manuel enviava ainda à Mina, todos os anos, 3 ou 4 naus com trigo, azeite, vinho e outros mantimentos destinados ao consumo do pessoal das feitorias e das guarnições militares (104). Os livros das chancelarias, guardados no Arquivo Nacional da Tôrre do Tombo, em Lisboa, fornecem preciosas achegas para a organização de quadros estatísticos dessa ordem. Esses produtos agrícolas eram, decerto, de procedência portuguêsa. E' o que se nos afigura. O vinho e o azeite provinham do reino. O trigo seria açoreano, já que no século XVI, com a retração cerealífera da ilha da Madeira (105), os Açores tornaram-se o celeiro de Portugal (106).

Com o enorme crescimento da emprêsa colonial, a administração régia tornou-se mais rigorosa. Daí a necessidade de se criarem novos organismos de policiamento do tráfico ultramarino a par da antiga alfândega de Lisboa. Os novos estabelecimentos administrativos constituiam órgãos de contrôle da Corôa inteiramente separados da velha alfândega, funcionando em edifícios próprios e com funcionários à parte.

Disso resultou a montagem, no ultramar e na Europa, de feitorias, autênticas sucursais das Casas de Lisboa, com escritórios e armazéns dirigidos por agentes econômicos da realeza com funções essencialmente comerciais.

Organizadas as rotas atlânticas do ouro africano e das especiarias asiáticas, a monarquia portuguêsa limitou-se a uma economia de transporte - comprar ou resgatar, levar para o. reino e distribuir pela Europa. Essa política mercantil explica, assim, a criação das feitorias no patrimônio afro-asiático, as Casas de Lisboa e o escritório comercial de Antuérpia, res-

\footnotetext{
(102). - Ibidem, cap. VII, pág. 71 .

(103). I Ibidem.

(104). - Ibidem.

(105). - Antes de 1461, a Madeira produzia trigo. De 1470 em diunte, a tha vive do açúcar, artigo mais rendoso. Só mais tarde, já nos fins do século XVI, os madeirenses dedicaram-se ao cultivo đa vinhu. (Cf. Serrão, J. - Sôbre - trigo das ilhas nos séculos XV e XVI, in Das Artes e da História dir Madeira, v. I, n. ${ }^{\circ}$ II, págs. 3 e segs., agôsto, 1950; Em tôrno Ha economia madeitanse, de 1580-1640. Ibidem, $n 0^{\circ} 1$ junho, 1950; Godinho, V. $M$. - Documentos sobre a expansāo portư̧uêsa, v. II, pág. 361. Lisboa, s. d.

(106). - Cf. Costa, Cameiro da - Os Açores e o problema cerealifero portuduês do século $X V$, in Boletim da Comissäo Reguladora dos Cereais do Arquivo dos Açores, Ano I, n.o 1, págs. 13 e segs., janeiro, 1945.
} 
pectivamente organizadas para comprar, receber e distribuir. Com essa orgânica econômico-administrativa, a realezà explorou diretamente o seu "Eldorado" ultramarino.

Com D. Manuel, a intervenção estatal e a prática do monopólio chegam ao apogeu do dirigismo régio. O contrôle está sempre presente, rigoroso e fiscalizador. Para isso cria-se uma legislação especial de acentuada estatização. Tudo é pensado e minuciosamente legislado. A base, o fundamento econômico de todo o edifício jurídico assenta na exploração régia do patrimônio. O tráfico é reservado para o soberano ou, em casos especiais, para certos empresários particulares afortunados, largamente aquinhoados pelos favores da monarquia.

A lei de Afonso $\mathrm{V}$ de 31 de agôsto de 1474 já delineara, sucintamente, êsse caráter estatal da emprêsa régia, proibindo viagens à Guiné sem autorização da Corốa, sob pena de morte e perda de todos os bens dos trangressores (107). A estatização foi crescendo numa sufocante progressão geométrica até alcançar o seu mais alto grau com o rigoroso dirigismo manuelino.

As Ordenações do Reino e os Regimentos dados pela realeza aos oficiais do ultramar e das Casas de Lisboa constituem preciosas achegas para se conhecer o espírito do intervencionismo estatal nos processos de exploração econômica do tráfico oceânico.

O rei é o dono da emprêsa - o grande capitalista. Dêle depende tôda e qualquer viagem legalmente realizada. Sem sua licença ninguém podia ir ou mandar navios ao ultramar "sob pena de fazendo-o morrer por isso de morte natural e por êsse mesmo feito perder para nós todos seus bens" (108). Idêntica pena para os que roubassem ou apresassem navios e mercadorias dos empresários que, com licença do rei, resgatavam na Guiné (109). Para isso a Corôa dava a todo capitão, pilôto, mestre ou senhorio dos navios do monarca ou dos particulares contratadores, "e assi a outra qualquer gente destes Reinos que às ditas partes e mares per seus privilégios ou nossas licenças poderem ir", que encontrassem navios em infração, o poder de apresar os barcos e fazer prisioneiras as suas tripulações, levando tudo para Lisboa onde o caso seria julgado pelo Juiz da fndia e Mina. Provado o delito, a prêsa se-

(107). - A.N.T.T. M. 1.0 de Leis, n.o 178.

(108). - Quinto Livro das Ordenaçäes, tit. CVII, pág. 392.

(109). Ibidem. 
ria dividida ao meio - metade para o apresador, metade 'para a Corôa (110).

Com o firme propósito de defender os resgates da Mina, a realeza determinava a quantidade e espécies de mercadorias que deviam ser embarcadas. O Estado proibia a tôda e qualquer pessoa, "assi estrangeira como natural", mandar ou levar para a "Terra dos Negros" contas, conchas, lambéis, ferro (111), manilhas de latão e de cobre, panos vermelhos e amarelos e outros artigos de procedência européia e marroquina de grande aceitação comercial nos centro de resgate do ocidente africano (112). Os infratores, pùblicamente açoitados, perdiam a carga e eram degredados para o Brasil (113). O acusador, sendo particular, era premiado com $1 / 3$ do valor dos bens apreendidos. No caso de ser oficial do rei, receberia a metade (114). Sendo o contrabando de ferro, o denunciador amealharia 50 por cento, fôsse êle quem fôsse (115).

No caso do transgressor ser o próprio capitão da cidade de São Jorge da Mina, perderia para a Corôa todos os seus bens e o ordenado da dita capitania, "e lhe será mais dada qualquer outra pena até morte natural que nos parecer que merece" (116). Se fôsse alcaide-mor, feitor, escrivão ou outro qualquer oficial ou morador da cidade da Mina, bem como aos capitães dos navios reais, a pena, além da perda dos bens, seria de "morte natural" (117).

Sendo o contrabando de valor inferior a 6 marcos de prata, os infratores perderiam em favor da realeza todos os seus soldos e mantimentos, incorrendo, outrossim, em outra qualquer pena cível e crime a critério do rei, até perda de todos os seus haveres, móveis e de raiz, e degrêdo perpétuo para o Brasil (118). A estas penas estava sujeita tôda e qualquer pessoa conivente com o contrabando ou que, tendo dêle conhecimento, não o denunciasse à justiça régia (119). Outrossim, todo resgate ilícito feito na Guiné, cujo valor fôsse igual ou superior a um marco de prata, a pena seria de "morte natural".

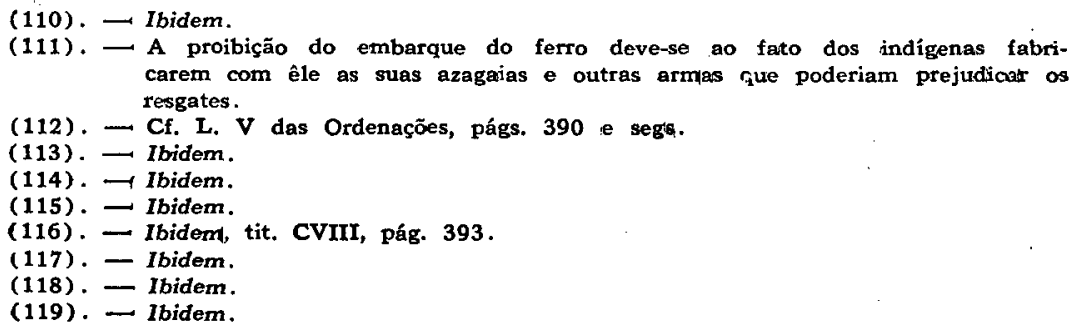


Sendo, no entanto, o montante inferior a essa importância, o infrator seria punido por crime de furto, perdendo, em ambos os casos, todos os seus bens para a Corôa (120).

Aos guardas dos navios e caravelas das rotas da Guiné, ao meirinho da cidade de São Jorge da Mina e aos demais oficiais do rei encarregados do policiamento e verificação das mercadorias embarcadas em Lisboa com destino aos centros de permuta da "Terra dos Negros", era aplicada a pena de morte se ficasse provado o embarque ilícito de qualquer carga com valor igual ou superior a 4 marcos de prata. Além disso teriam seus bens confiscados pelo Estado No caso do contrabando ser inferior a essa importância, os funcionários transgressores, embora escapassem da pena máxima, perderiam todos os seus haveres (121).

Os carregamentos de torna-viagem sòmente em Lisboa podiam ser legalmente descarregados. Uma vez no reino, eram encaminhados para os armazéns da Casa da Mina. onde eram despachados pelos oficiais do rei (122) .

Os capitães de navios, fôssem da Corôa ou de contratadores, que partiam de Portugal com destino à Guiné, só podiam atracar no pôrto de resgate, sob pena de perderem todos os seus bens e serem degredados por 5 anos para a Africa (123). No regresso, a contravenção era agravada com outra pena, civel e crime, que ficava a critério do monarca (124).

Em caso de arribada forçada, proibia-se quaisquer descarregamentos. Tampouco podiam descer a terra senão os homens ordenados pelo capitão do navio para consêrto e aprovisionamento do barco. Havendo autoridade portuguêsa no local, a comunicação com a terra só podia ser feita depois do conhecimento e permissão do respectivo capitão ou oficial (125).

Chegando ao pôrto de destino, os capitães dos navios não estavam autorizados a lançar batel fora, nem pessoa alguma sair do barco, sem primeiro receber a devida licença do capitão da fortaleza ou, na falta dêste, do feitor ou de outro oficial do rei. Em caso contrário perderiam todos os seus bens para a Corôa e seriam degredados por 10 anos para o Brasil (126).

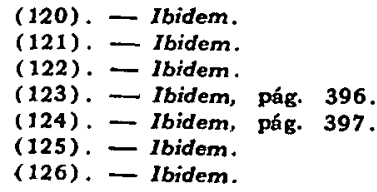


Em Lisboa, os navios só podiam atracar depois de ir a bordo o juiz da Guiné ou outros oficiais encarregados de verificar a carga. Só depois de obtido o devido despacho da "polícia marítima" do rei, é que o capitão do navio podia lançar o batel fora e providenciar o desembarque. O transgressor perderia seus haveres e seria degredado por 5 anos para a Africa. Se o infrator fôsse outra pessoa, perderia o sôldo e seria açoitado pùblicamente. Sendo "pessoa em que não caibão açoites", seria degredado por 5 anos para o Brasil (127).

No reino, Lisboa era o único pôrto legal de carga e descarga. Em caso de arribada forçada noutro pôrto português, todo o ouro transportado devia ser desembarcado e seguir por terra para a capital. Ao escrivão do navio cabia, neste caso, registrar em seus livros de bordo as razões do desastre para conhecimento e providências, do rei (128).

A nenhum capitão, pilôto, mestre, marinheiro ou outra qualquer pessoa que embarcasse nos navios das rotas da Guiné, era permitido levar arca, barca, nem outra vazilha, sob pena de perder todo seu ordenado da viagem e ser pùblicamente açoitado. No caso de ser pessoa "em que não caiba pena de açoutes", seria degredado por 2 anos para a Africa (129).

Os que partiam com ordens de regressar não podiam ficar na "Terra dos Negros" sob qualquer alegação. Aos transgressores era aplicada a pena de morte, além de perderem todos os seus bens para a Corôa. Ao capitão de navio, mestre ou pilôto, que deixasse ficar alguém, eram aplicadas idênticas penas. Aos delatores dava o Estado $1 / 3$ dos bens confiscados. Ao juiz da Mina e fndia cabia entregar a recompensa e providenciar o devido assentamento nos livros do escrivão, cujos têrmos deviam ser assinados pelo provedor, juiz e procurador (130).

As mercadorias resgatadas no ultramar, ou enviadas pelas tesourarias de Lisboa, só podiam ser transportadas em navios portuguêses. As penas eram rigorosas. No que respeita ao ouro, havia uma legislação minuciosa. O precioso metal amarelo que os feitores do rei resgatavam aos indígenas só podia ser legalmente transportado nos cofres da Corôa, fechados a "sete chaves" e entregues aos respectivos donos em Lisboa, depois de conferido pelos oficiais da Casa da Mina e de convertido em espécies monetárias na Moeda de Lisboa (131).

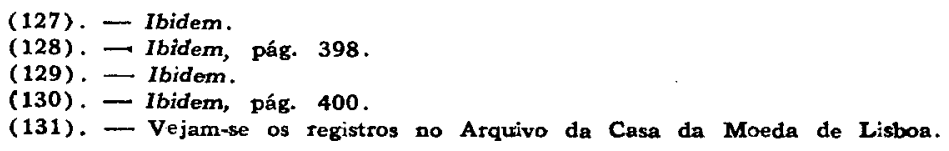


Com êsse dirigismo, a realeza procürava defender o seu patrimônio ultramarino. As feitorias - sucursais das Casas de Lisboa - não eram, no entanto, apenas organismos autárquicos e burocráticos de contrôle da audaciosa emprêsa régia. Elas representam, no quadro das relações econômico-financeiras internacionais, mais alguma coisa do que uma simples ampliação quantitativa do tráfico da Corôa. Representam para as trocas européias enormes possibilidades de abastecimento comercial de todo um mundo de nítidas feições capitalistas em franco crescimento. Refletem mesmo, embora numa imagem atrevida, e por isso mesmo um tanto deformada, a futura exploração do colonialismo das grandes potências nas suas investidas pela partilha do mundo afro-asiático.

A realeza, conservando a propriedade e com ela o monopólio do comércio, fêz dêsse patrimônio ultramarino um ambicionado capital. Dado o caráter monárquico da emprêsa econômica, ela se realiza num campo que também é político, militar e financeiro. $E$, note-se, é precisamente êsse acentuado caráter híbrido que dificulta, de certa maneira, a capitalização do gigantesco empreendimento régio enquanto comercial, uma vez que desvia capitais do tráfico. Em contrapartida, inaugura a colonização das novas terras em têrmos de estruturas capitalistas, inclusive no Brasil (132).

\section{MANUEL NUNES DIAS}

Professor de História Íbérica e Assistente da Cadeira de História da Civilização Moderna e Contemporânea da Faculdade de Filosofia, Ciências e Letras da Universidade de São Paulo.

(132). - Plara o caso do Brasil, veja-se o estudo de A. Marchant - Feudal and Capitalistic Elements in the Portusuese Settlement of Brazil, in The Hispanic American Historical Review, págs. 493 e segs. - agôsto, 1942. 